应例

肝・リンパ節転移をきたした多発胃平滑筋肉腫の 1 例

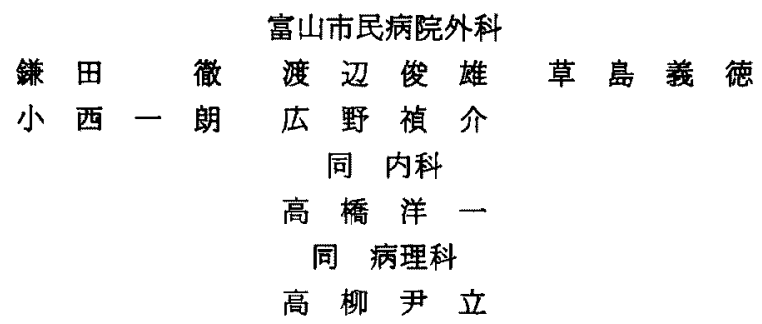

多発胃平滑筋肉尰の報告は非常にまれであり，これまでに本邦では1例が報告されて いるにすぎない：今回，リンバ節転移，旰転移をきたした多発㫣平滑筋肉腫の 1 例を経 検したので埌告する。

症例は47歳女性で，特発性門脈圧六進症を合併していたため，胃全摘，脺脾合併切除， 䀒転移合併切除を 2 期的に行った，平滑筋肉腫は胃上部に 2 個，胃体部に 1 個の計 3 個 認められ，組織学的にはいずれの腫湯す注ぼ同様の組織像で，筋㵶維夝生の多い比較的 分化した像と筋織維産生がはとんど認められず，核が類円形で epithelioid pattern を示 す像が湿在していた。リンバ節転移を 3 個，肝転移を 2 個認めた。術後にCisplatin, Etoposide, Mitomycin C の肝動注を行い, 術徙 1 年以上释過後も再発を認めていない.

索引用語：多発胃平滑筋肉連

\section{はじめに}

多発胃平滑笳肉腫の報告は非常にまれでありこれ までに本邦では淕田ら”の1例が報告されているにす ぎない，今回，リンハ節転移，肝転移をきたした多発 胃平滑筋肉腫の1例を経験したので報告する。

患者：47葴，女性。

$$
\text { 症例 }
$$

主訴：上腹部痛.

既往歴：25年前に脾嗹を指摘されている。

家族歴：特記すへさことなし。

現病歴：平成 1 年 8 月より上腹部痛を䜅め, 同年 12 月に当院を受診した。

入院時現症：左上腹部に巨大な腫瘤を認めた。

入院時検查成绩：赤血球 351 万 $/ \mathrm{mm}^{3}$ ，一モグロビン $9.0 \mathrm{~g} / \mathrm{dl}$, へマトクリット $29.6 \%$, 白血球 $1,400 / \mathrm{mm}^{3}$, 血小板 1.9 万 $/ \mathrm{mm}^{3}$ と，汎血球減少症を認め大，その他， 䀒機能, 睡䴓マーカー (carcinoembrionic antigen, $\alpha$-fetoprotein, CA19-9)などには異常を認めなかった。

1991年 5 月23日受付 1992年 3 月19日採用
胃透視(図 1): 粘膜下腫瘍様病変が胃上部前壁に 2 力所, 胃体部大弯に 1 カ所認められた。

胃内視鏡検查（図 2)：粘膜下隀瘍様病変が多発し, 一部には浩形成が諗められた。生検では group II で あった。

CT (図 3)：肝外側区域と S8に low density area を 認めまた巨大な脾腫も認められた。

以上上り，特発性門脈殴元進症による巨大脾腫と肝 転移を有する胃粘膜下腫骠の診断にて平成 2 年 2 月に 開腹した，手術は脾機能元進による血小板娍少が著明 のため 2 期的に行われた。まず脾䐵摘出と胃体部大弯 の腫瘍核出を行った，病理組織学的に胃平滑筋肉腫の 診断を 5 け, 平成 2 年 4 月に胃全摘, 膵尾部切除なら びに肝外側区域切除，S 8 部分切除, 肝動注リザーハー 埋め込みを行った。

胃の摘出標本（図 4)：胃上部前壁に最大径 $3 \mathrm{~cm}$ の 壁内型粘膜下腫湯が 2 個ならんで存在し(矢印)，口側 の腫湯には小さな溃焬形成が認められた。

ルーペ像（図 5)：2 個の粘膜下尰湯恃充実性で王排 性に增殖し，2個の畽湯の間には連続性は認められな 


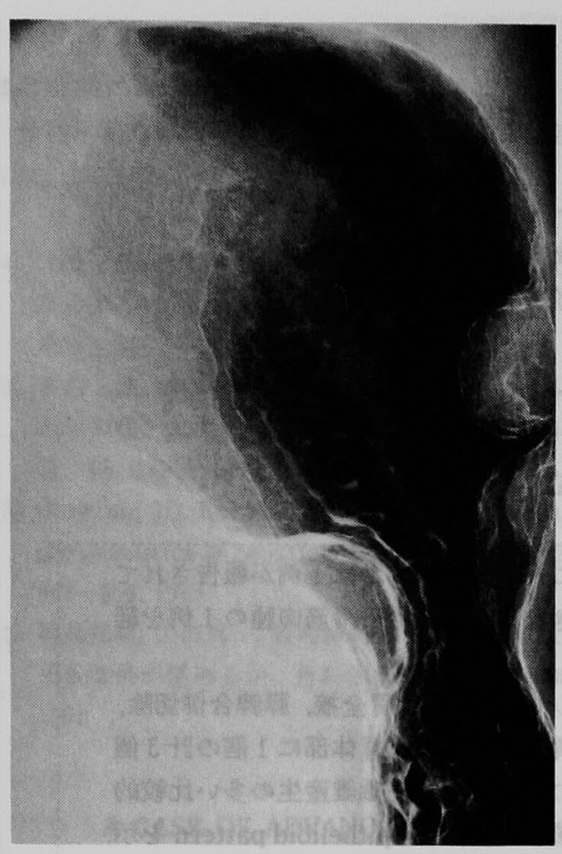

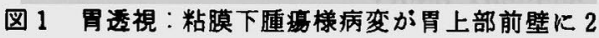

個, 胃体部大弯に 1 個認められる.

かった。

組織像（図 6 ）：胃にみられた 3 個の粘膜下尰浧は, いずれるほぼ同様の組織像で，筋瀻維産生の多い比較 的分化した像と筋㵶維産生がほとんど認められず，核 が類円形で epithelioid pattern を示す像が混在する平

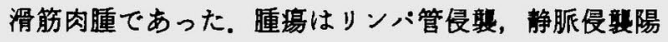

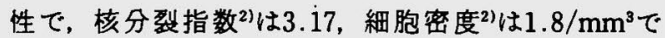
あった. Schutteら の)の方法に準じて求められた核 DNA ploidy pattern はdiploidであった。

リンパ節転移巣の組織像（図 7)：充実王排性の転移 を認め, 組䋨学的には epithelioid pattern を示す平滑 筋肉腫であった.リンパ節転移はNo. 3 に 2 個, No. 4 $\mathrm{sb}$ に 1 個, 計 3 個認められた。肝外側区域, S8の転移 栄も同様の組織像を呈していた。

\section{考察}

胃平滑筋肉腫の多発例の頻度は Skandalakis ら"に よると約10\%であるとしまたAbramson (5)は leiomyoblastoma の6.8\%が多発例であったとしてい るが，本邦ではこれまで 1 例が報告”されているにす ぎず，平滑㳙肉腫の多発例は極めてまれであると考え られた。本症例では胃上部に 2 個, 胃体部に 1 個の計 3 個の平滑筋肉腫が認められた。これらは組織像が同
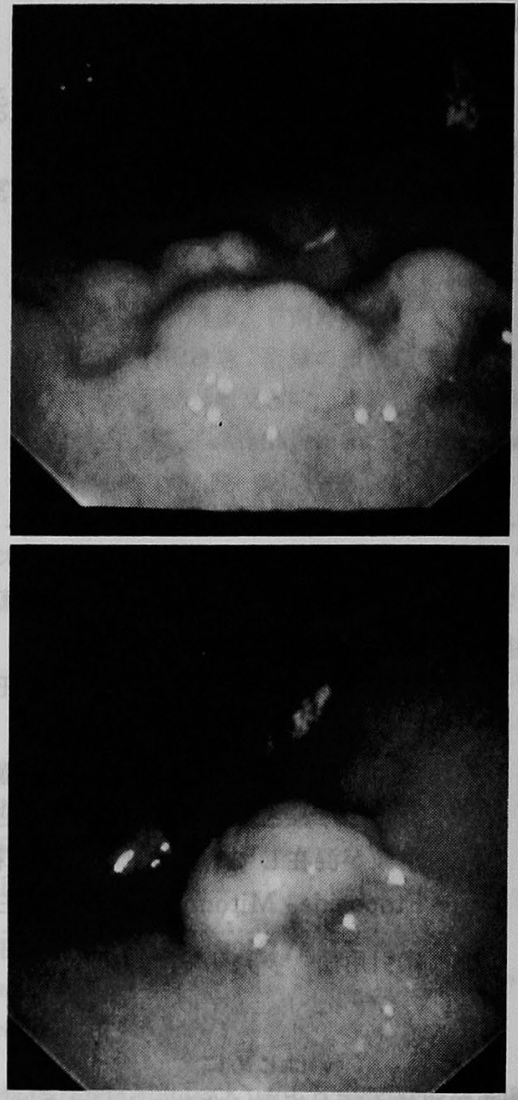

図 2 男内視篰検査所見：上段；胃上部に中心陷凹を 有する 2 個の粘膜下連瘄様病変が並んで存在する。 下段：胃体大弯に bridging fold を有する粘膜下腫

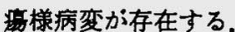

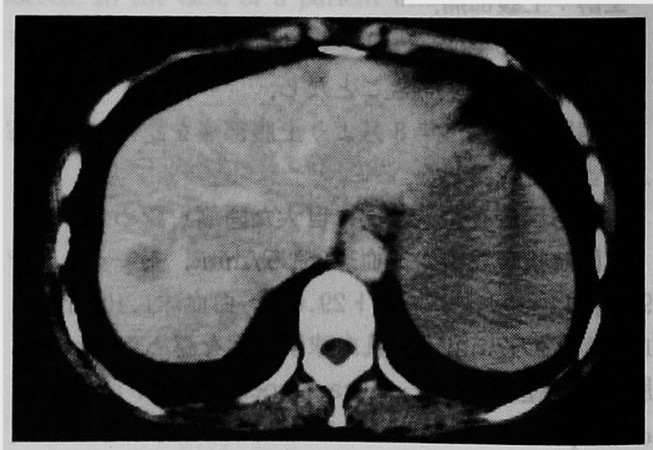

図 3 腹部 CT : 肝外側区域と S8に 2 個の low density areaを認め, また巨大な脾腫も認められる.\%1 


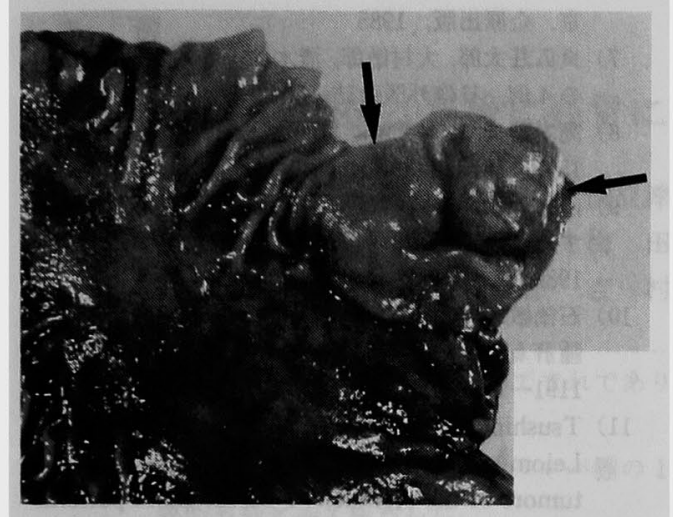

图4のの揞出标本：胃上部前壁に最大经 $3 \mathrm{~cm}$ の壁 内型粘膜下睡瘦が 2 個ならんで存在し(知印)， 口側

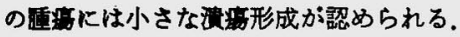

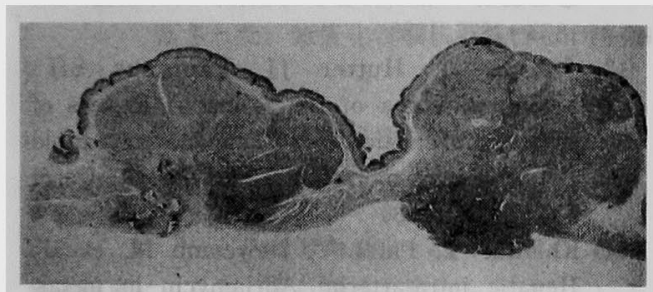

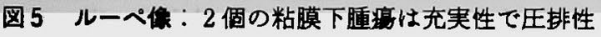
に増殖し， 2 個の尰痔の間には連続性は認められな w.

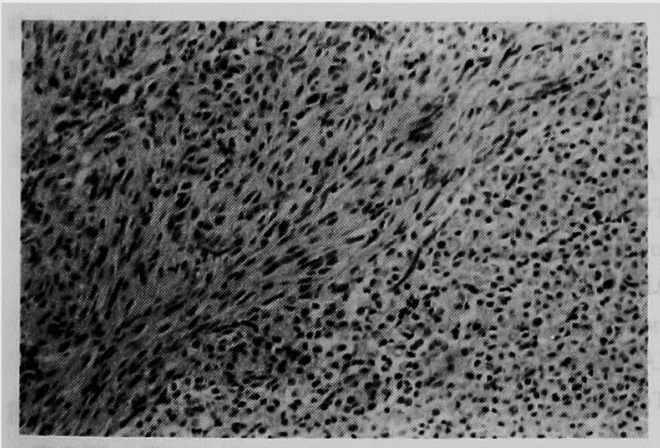

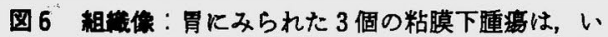
ずれすほぼ同様の組織像で，筋繊維産生の多い比較 的分化した像之筋織維産生がほとんど認められず, 核が類円形で epithelioid patternを示す像が混在 する平滑笳肉尰である。

じで、リンパ管侵咅，静脈侵襲を認めたことより，壁 内転移の可能性は完全には否定できないが, 腫瘍径が

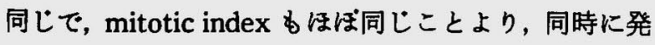

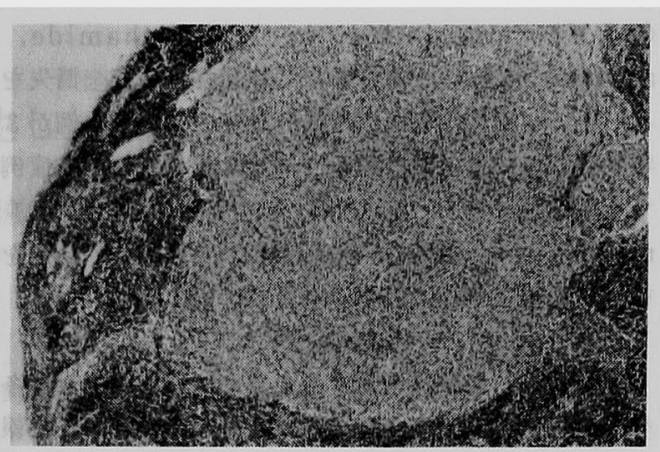

図 7 リンパ節転移栄の組織像：充実王排性の転移を 認め, 組織学的には epithelioid pattern を示す平滑 筋肉腫である。

生した多発平滑能肉腫であると考えた。

本症例では，リンバ節転移を「胃癌取扱い規約」泉に 基つくと、第 1 群リンパ節である No. 3, No. 4sbに認 めた.これまでの胃平滑筋肉腫のリンパ節転移率は 0 〜 $18 \%$ と報告》され，かなりのバラッキがみられてい る.これに伴い, 手術方法も局所切除で良いとする施 設2)や十分なリンバ節郭清を行うために胃癌に準じた 手術を行っている施設淿むあり，手術法については未 たに一定の見解は得られていないか，胃平滑筋肉腫の リンパ節転移は皆無ではないことより,少なくとも「胃 癌取扱い規約 ${ }^{6)}$ の $\mathrm{R}_{1}$ のリンバ節郭清が必要であると 考えられる。

肝転移率は貞広ら゙によると，24.2\%であったとし， 胃平滑筋肉腫は血行性転移をきたし易いと言われてい る. 本症例では肝外側区域と後上区域に 1 個ずつの転 移を認め, 合併切除ならびに肝動注リザーバー埋め込 みを行った. 胃癌の場合, 肝転移巣の合併切除を行っ ても，その予後は亟めて不良であり, 平均生存期間は 1 年以下と報告されている" が，平滑筋肉腫では，比較 的長期生存例の報告(10)がなされており，合併切除の意 義はあると考えられるが，今後，多数例での検討が望 まれる。

消化管平滑筋肉腫の悪性度の指標として,これまで に尰痬径, 核分裂指数, 細胞密度ならびに核 DNA 量が 重要であると報告されている2111)12). 本症例ではそれぞ れ径3cm, $1.8 / \mathrm{mm}^{3}, 3.17$, diploid であった.これら の值は諸家の報告2)(1)12)によれば予後良好であるとさ れている.

本邦では胃平滑筋肉腫に対する化学療法の効果に関 する報告はなされていないが，欧米では adriamycin 
(ADM), vincristine, cyclophosphamide, actinomycin D の全身投与にて肝転移巣の完全消失を みたといら報告191やADM の肝動注にて肝転䔟例が 3 年生存しているといら報告"かがなされて括り，本症例 でも肝動注りザーバーを介して, cisplatin (CDDP) mitomycin C (MMC) etoposide (VP-16) の動注を 行い, 術後 1 年経過後再発を認めていない。

$$
\text { 結語 }
$$

肝，リンバ節転移を有する本邦では極めてまれな多 発平滑筇肉連の 1 例を経験し，文献的考察を加克て報 告した.

\section{文献}

1) 窪田 久, 和田，三輪样人地：多発性胃平滑筋 肉尰の 1 例，消内視鏡の進歩 $30: 267-270,1987$

2) 北岡久三, 岡林絴蔵, 木下 平他：胃平滑筋肉連の 予後因子亡手術法，とくに局所切除の適応につい て, 澏の臨 $29: 811-816,1983$

3) Schutte B, Reynders MMJ, Bosman FT, et al : Flow cytometric determination of DNA ploidy level in nuclei isolated from paraffin-embedded tissue. Cytometry 6: 26-30, 1985

4) Skandalakis JE, Gray SW, Shepard D: Smooth muscle tumors of the stomach. Int Abstr. Surg. 110: 209-226, 1960

5) Abramson DJ: Leiomyoblastomas of the stomach. Surg Gynecol Obstet 138: 118-125, 1973

6）胃癌研究会編：胃癌取扱い規約，改訂第11版，東
京, 金原出版, 1985

7) 貞広荘太郎，大村敏郎，清水壮一他：胃平滑筋肉腫 の4 例，日臨外医会誌 $50: 1171-1175,1989$

8）高木国夫，山本英昭：俏䐊管平滑筋肉盾，消外 5 ： $1507-1513,1982$

9）山村義孝, 紀藤 媇，中里博昭：同時性旰転移を有 する胃癌の治療，日消外会誌 22：1067-1071， 1989

10）石橋敏光，安田是和，落合聖二他：消化管平滑筋肉 腫肝転移例の臨床的検討，日胸外医会誌 51 ： 1191-1199, 1990

11) Tsushima $K$, Rainwater LM, Goellner JR, et al : Leiomyosarcomas and benign smooth muscle tumors of the stomach: Nuclear DNA patterns studied by flow cytometry. Mayo Clin Proc 62 : 275,1987

12）角谷直孝，类村 豊，大山繁和他：消化管平滑筋性

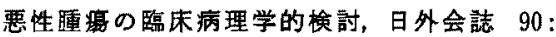
$1873-1877,1989$

13) Jonson H, Hutter JJ, Paplanus SH : Leiomyosarcoma of the stomach: Results of surgery and chemotherapy in an eleven year old girl with liver metastases. Med Pediatr Oncol 8: $137-142,1980$

14) Khansur $T$, Patel V, Newcomb $M$, et al: Hepatic intra-arterial Adriamycin in metastatic leiomyosarcoma: Exploiting the steep dose-response curve. J Surg Oncol 36:76-79, 1987

\title{
A MULTIFOCAL GASTRIC LEIOMYOSARCOMA WITH LIVER AND LYMPH NODE METASTASES
}

\author{
Toru KAMATA, Tetsuya INOUE, Toshio WATANABE, Kiyoshi TAJIRI, Yoshinori KUSAJIMA, \\ Ichiro KONISHI and Teisuke HIRONO \\ Department of Surgery, Toyama City Hospital \\ Yoichi TAKAHASHI \\ Department of Internal Medicine, Toyama City Hospital \\ Nobutatsu TAKAYANAGI \\ Department of Pathology, Toyama City Hospital
}

Multifocal leiomyosarcoma of the stomach is very rare. In Japan, only one case was reported. A multifocal gastric leiomyosarcoma with liver and lymph node metastases in a 47-year-old woman is discribed. Because of associated idiopathic portal hypertension, total gastrectomy with pancreatosplenectomy was performed in a two. step approach. The resected specimen showed two tumors in an upper portion of the stomach and a tumor in the body. Histologic examination revealed similar findings in all the tumors, which were composed of a differentiated portion with abundant smooth muscle fibers and a portion with epithelioid pattern. Three positive lymph nodes and two metastatic lesions of the liver were found histologically. After resection, chemotherapy with cisplatin, etoposide and mitomycin $C$ through an intra-hepatic arterial catheter was performed. The patient have no recurrence over 1 year after operation. 